\title{
PURIFICATION AND CHEMICAL CHARACTERIZATION OF THE MAJOR TOXINS FROM THE VENOM OF THE BRAZILIAN SCORPION TITYUS SERRULATUS LUTZ AND MELLO
}

\author{
by \\ LOURIVAL DOMINGOS POSSANI \\ Universidad Nacional Autónoma de Mexico, Instituto de Investigaciones Biomédicas, \\ Apartado Postal 70-247 México 20 D.F., Mexico. \\ and \\ Max-Planck-Institut für Ernährungsphysiologie, \\ Rheinlanddamm 201, D-4600 Dortmund, * \\ BRIAN M. MARTIN, JAVIER MOCHCA-MORALES \\ Max-Planck-Institut fur Ernährungsphysiologie, \\ Rheinlanddamm 201, D-4600 Dortmund \\ and \\ IB SVENDSEN \\ Department of Chemistry, Carlsberg Laboratory, \\ Gamle Carlsberg Vej 10, DK-2500 Copenhagen, Valby
}

Keywords: Scorpion toxins, Tityus serrulatus, amino acid analysis, amino acid sequence, sequence homology

The soluble venom from the Brazilian scorpion Tityus serrulatus Lutz and Mello was fractionated on Sephadex G-50 followed by ion exchange chromatography in carboxymethyl-cellulose, resolving at least 10 different toxic components. In this communication the purification and chemical characterization of four major components is reported. The toxins were found to be single polypeptide chains with molecular weights of approximately 7,000, 61-63 amino acid residues and four disulphide bridges. Amino terminal sequence determination of these toxins after reduction and alkylation revealed three unique sequences up until residue fourty-one. For toxin II-11 (14) and toxin III-10 the N-terminal sequence is: Lys-Glu-Gly-Tyr-Leu-Met-AspHis-Glu-Gly-Cys-Lys-Leu-Ser-Cys-Phe-Ile-Arg-Pro-Ser-Gly-Tyr-Cys-Gly-Arg-Glu-Cys-Gly-Ile-Lys-Lys-GlySer-Ser-Gly-Tyr-Cys-Ala-Trp-Pro. Toxin III-8 has the following N-terminal sequence: Lys-Glu-Gly-Tyr-AlaMet-Asp-His-Glu-Gly-Cys-Lys-Phe-Ser-Cys-Phe-Ile-Arg-Pro-Ala-Gly-Phe-Cys-Asp-Gly-Tyr-Cys-Lys-ThrHis-Leu-Lys-Ala-Ser-Ser-Gly-Tyr-Cys-Ala-Trp-Pro. Toxin IV-S has the N-terminal sequence: Lys-Lys-AspGly-Tyr-Pro-Val-Glu-Tyr-Asp-Asn-Cys-Ala-Tyr-Ile- Cys-Trp-Asn-Tyr-Asp-Asn-Ala-Tyr-Cys-Asp-Lys-LeuCys-Lys-Asp-Lys-Lys-Ala-Asp-Ser-Gly-Tyr-Cys-Tyr-Trp-Val.

* As visiting professor of the Alexander von Humboldt Foundation. 


\section{INTRODUCTION}

Scorpion toxins are polypeptides containing from 36-70 amino acid residues cross-linked by four disulphide bridges $(1,11,20,23)$. These toxic peptides have attracted the attention of many groups of scientists because they interfere with basic events that normally take place in biological membranes $(4,8,18,20)$. The best characterized scorpion toxins are from specimens collected in North Africa or North America $(1,3,7,12,15,20)$. We have previously shown (14) that the venom of the South American scorpion T. serrulatus contained several toxic components, from which toxin II-1I $(\gamma)$ has been that most studied. Some preliminary results on the three-dimensional structure of these molecules have recently been published (17). Nevertheless, the complete primary structure of the toxins from $T$. serrulatus scorpion venom is not known. This paper attempts to give further information on the chemical composition and amino terminal amino acid sequence of the four major mammalian toxins purified from the venom of $T$. serrulatus. Part of this data was presented during the 4th European Symposium on Animal, Plant and Microbial Toxins (16).

\section{MATERIALS AND METHODS}

\subsection{Materials}

The venom from the scorpion $T$. serrulatus was a gift from the Instituto Butantan, São Paulo, Brazil. The dried venom was kept at $-20^{\circ} \mathrm{C}$. When needed, it was dissolved in 0.02 M-ammonium acetate buffer, $\mathrm{pH} 4.7$, at an approximate concentration of $80 \mathrm{mg} \cdot \mathrm{ml}^{-1}$ and spun down in a Sorval Centrifuge (rotor SS-34, $15,000 \mathrm{rpm}$ for 15 minutes). The supernatant called soluble venom, was used for lethality tests and preparation of the individual toxins.

Sephadex G-50 (medium and fine) were products of Pharmacia Fine Chemicals, Uppsala, Sweden. Carboxymethyl cellulose, CM-32, was purchased from Whatman Inc., Clifton, New
Jersey. Dialysis tubing, Spectrapor Type 3 with a molecular weight cutoff of approximately 3500 was from Spectrum Medical Industries, Los Angeles, Ca., USA. Dithiothreitol was from Calbiochem-Behring Corp., La Jolla, Ca. and 4Vinylpyridine was a product of Merck-Schuchardt, West-Germany.

For sequence determinations the following chemicals were employed. Polybrene, phenylisothiocyanate, heptafluorobutyric acid, 1-propanol, trifluoroacetic acid, butylchloride and benzene were all Sequanal grade reagents from Pierce Chemicals, Rockford, Ill., USA. Sequenator grade heptane was obtained from Fluka AG, Switzerland. N, N, N', N'-tetrakis(2-hydroxyethyl)ethylene diamine (THEED) was obtained from ICN-K\&K Laboratories Inc., Plainview, N.Y. and used without further purification. Ethyl acetate (UV solvent grade) was purchased from Merck Chemicals, West Germany. Both THEED and ethylacetate were found to be free of aldehydes as determined by the Tollen's reaction (6).

All other chemicals were analytical reagent grade. Distilled water was used throughout.

\subsection{Lethality tests}

The mouse lethality of various protein fractions was observed after intraperitonial injection of different amounts of protein in $0.1-0.3 \mathrm{ml}$ of $\mathrm{NaCl}$ (or ammonium acetate buffer) into adult 18-20 $\mathrm{g}$ albino mice (strain NMRI). The $\mathrm{LD}_{50}$ of the soluble venom was obtained graphically by plotting the percentage of deaths at $20 \mathrm{~h}$ versus the logarithm of the dose (ten mice at each dose and twelve different doses of increasing concentration). To define the toxicity of the various chromatographic components, three designations were used. "Lethal" means that the component at the dose injected was enough to kill the tested mouse within $20 \mathrm{~h}$ of injection. "Toxic" means that the mouse shows any of the following symptoms: excitability, salivation, temporary paralysis of rear limbs, dyspnea but

Abbreviations: $\mathrm{CM}=$ carboxymethyl, DTT $=$ dithiothreitol, HPLC $=$ high performance liquid chromatography, $\mathrm{PE}=$ reduced and pyridylethylated, Polybrene $=$ 1,5-dimethyl-1,5-diazundecamethylene polymethobromide, PTH = phenylthiohydantoin. THEED = N, N, N', N'-tetrakis(2-hydroxyethyl)ethylene diamine, $\mathrm{T}$. $=$ Tityus. 
recovered within $20 \mathrm{~h}$ after injection. "Nontoxic " means normal behaviour similar to injection of $0.9 \% \mathrm{NaCl}$. Protein concentration, unless otherwise specified, was measured by spectrophotometry assuming that $1 \mathrm{~A}_{280 \mathrm{~nm}}^{1 \mathrm{~cm}}$ unit $=1 \mathrm{mg} \cdot \mathrm{ml}^{-1}$.

\subsection{Purification of toxins}

The purification procedure followed in this work is a modification of that previously published (14). Initial fractionation of the soluble venom was accomplished using a large Sephadex G-50 column $(1.8 \times 200 \mathrm{~cm})$ equilibrated and eluted with $0.02 \mathrm{~m}$-ammonium acetate buffer, pH 4.7 (Figure 1). The toxic fractions II, III and IV were each subsequently submitted to ion exchange chromatography on CM-cellulose. The CM-cellulose columns were previously equilibrated with $0.02 \mathrm{M}$-ammonium acetate, $\mathrm{pH} 4.7$ and, after sample application, developed with a

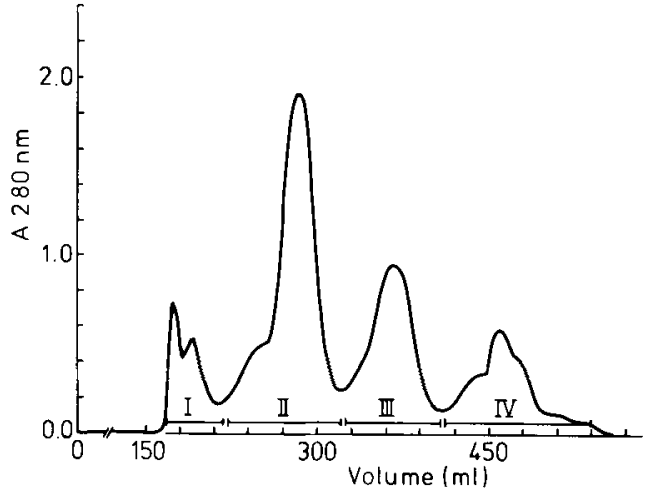

Figure 1. Fractionation of the soluble venom

A $1.8 \times 200 \mathrm{~cm}$ column of Sephadex G-50, medium, equilibrated with $0.02 \mathrm{M}$-ammonium acetate, $\mathrm{pH} 4.7$ was loaded with $3.8 \mathrm{ml}$ of soluble venom containing 192 absorbance units at $280 \mathrm{~nm}$ and eluted with the same buffer at a flow rate of $24 \mathrm{ml}^{-1}$. Fractions of $3 \mathrm{ml}$ were collected and pooled as indicated by the horizontal bars. For recoveries and lethality tests see Table I. linear gradient of $\mathrm{NaCl}$ from 0 to $0.55 \mathrm{M}$ as indicated in Figures 2 to 4 . The major toxic components were rechromatographed on $\mathrm{CM}$ cellulose (Figures 5 and 6). Polyacrylamide gel electrophoresis in the $\beta$-alanine-urea system of

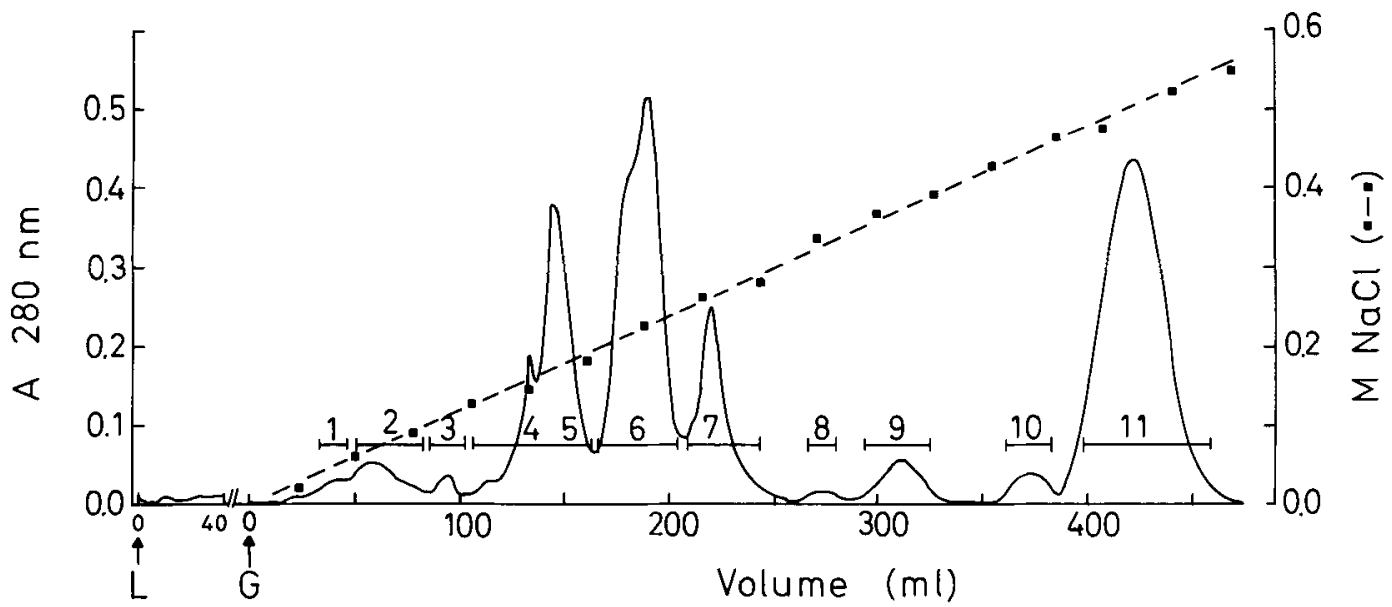

Figure 2. Ion exchange separation of the fraction II from Sephadex G-50.

A $0.9 \times 27 \mathrm{~cm}$ column of CM-32 equilibrated with 0.02 M-ammonium acetate. $\mathrm{pH} 4.7$ was used. Fraction II (44 absorbance units at $280 \mathrm{~nm}$ in $40 \mathrm{ml}$ ) was loaded, followed by passage of the equilibration buffer. A linear gradient containing $240 \mathrm{ml}$ each of equilibration buffer and this buffer containing $0.55 \mathrm{M}-\mathrm{NaCl}$ was started as indicated. The flow rate was $28 \mathrm{ml} . \mathrm{h}^{-1}$ and fractions of $1.85 \mathrm{ml}$ were collected. The fractions were pooled as shown by horizontal bars and overall recovery of applied material was $95.3 \% \mathrm{~L}=$ loading, $\mathrm{G}=$ start of gradient. 


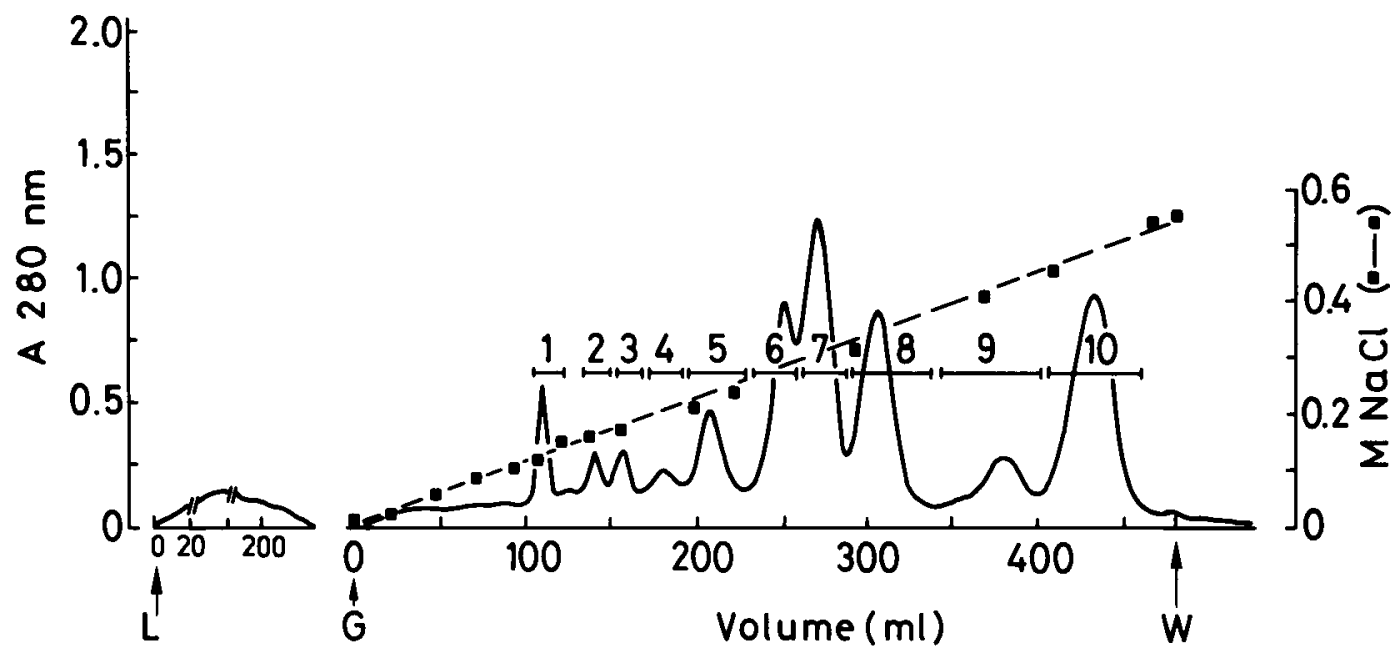

Figure 3. Ion exchange separation of the fraction III from Sephadex G-50.

A $0.9 \times 27 \mathrm{~cm}$ column of CM-32 equilibrated with $0.02 \mathrm{M}$-ammonium acetate, $\mathrm{pH} 4.7$ was loaded with fraction III ( 103 absorbance units at $280 \mathrm{~nm}$ in $220 \mathrm{ml}$ ) and eluted under conditions identical to those in Figure 2. Fractions of $2.4 \mathrm{ml}$ were collected and pooled as indicated by the horizontal bars. Recovery was $95.7 \% . \mathrm{L}=$ loading, $\mathrm{G}=$ start of gradient, $\mathrm{W}=$ start of high salt wash.

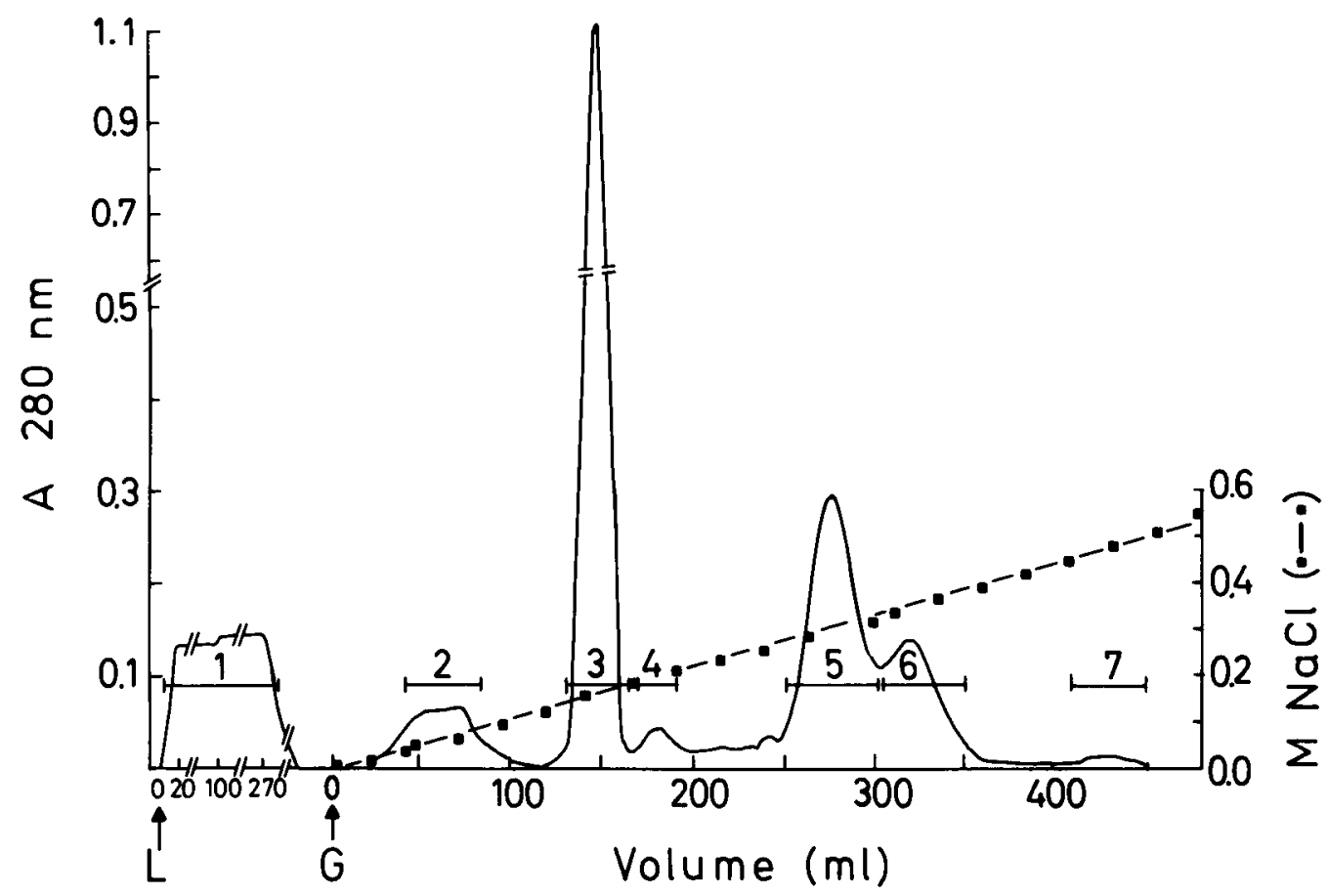

Figure 4. Ion exchange separation of the fraction IV from Sephadex G-50.

A $0.9 \times 27 \mathrm{~cm}$ column of CM-32 equilibrated with $0.02 \mathrm{M}$-ammonium acetate, $\mathrm{pH} 4.7$ was loaded with fraction IV (72.3 absorbance units at $280 \mathrm{~nm}$ in $273 \mathrm{ml})$ and eluted under identical conditions as in Figure 2. Fractions of $2.0 \mathrm{ml}$ were collected and pooled as indicated by the horizontal bars. Overall recovery was $98.3 \%$. $\mathrm{L}=$ loading, $\mathrm{G}=$ start of gradient. 
L. D. Possanı et al.: Scorpion toxin sequences

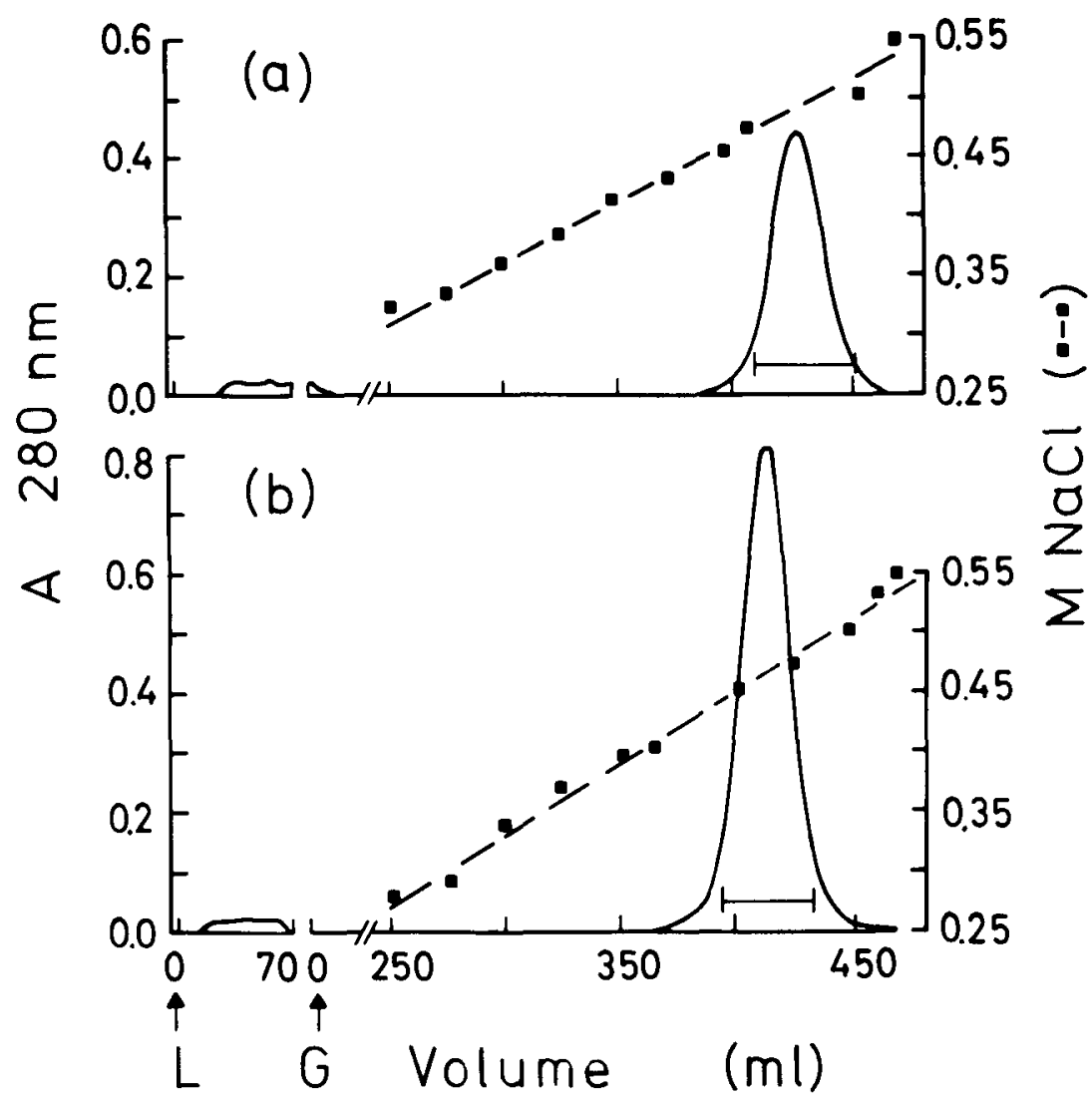

Figure 5. Final purification of Toxins II-11 and III-10.

Fractions II- 11 and III- 10 were rechromatographed on CM-cellulose under the same elution conditions as for Figure 2. The flow rate was $30 \mathrm{ml} . \mathrm{h}^{-1}$ and fractions of $2.4 \mathrm{ml}$ were collected and pooled as indicated by the horizontal bars.

a) Fraction II-11. 13 absorbance units at $280 \mathrm{~nm}$ in $70 \mathrm{ml}$ equilibration buffer were loaded. Toxin II-11, as recovered, constituted $90 \%$ of the material applied.

b) Fraction III-10. 22 absorbance units at $280 \mathrm{~nm}$ in $62 \mathrm{ml}$ equilibration buffer were loaded. Toxin III-10 amounted to $86 \%$ of the material applied, $\mathrm{L}=$ loading, $\mathrm{G}=$ start of gradient.

REISFELD (19) was used to determine the homogeneity of the isolated toxins. Toxicity to mice was ascertained after each step of chromatography. Dialysis to remove salt after each of the $\mathrm{CM}$-cellulose steps was made against water or appropriate buffer.

\subsection{Reduction and pyridylethylation}

Reduction of the scorpion toxins was accomplished using Dithiothreitol (DTT). Typically, 1 $\mathrm{mg}$ toxin $(\simeq 150$ nmoles protein) was dissolved in $1 \mathrm{ml}$ of $0.2 \mathrm{M}$-Tris- $\mathrm{HCl}$ buffer, $\mathrm{pH} 8.6$, containing $1 \mathrm{mg}$ EDTA and 6 M-guanidine hydrochloride. One drop of 1 -octanol was added and the solution purged with a stream of $\mathrm{N}_{2}$ for 10 minutes. DTT $(1.54 \mathrm{mg}, 10 \mu$ moles $)$ was added and the solution was purged an additional 10 minutes with $\mathrm{N}_{2}$. After 2 hours at $35^{\circ} \mathrm{C}$ the reduced toxin was alkylated by addition of 4 . vinylpyridine $(10 \mu \mathrm{l}, 92 \mu$ moles $)$. After 30 minutes at room temperature, the reduced pyridylethylated toxin was chromatographed on a Sephadex G-50 (fine) column $(2.5 \mathrm{~cm} \times 120$ $\mathrm{cm}$ ) using $20 \%$ acetic acid as eluant. The protein 
L. D. Possani et al.: Scorpion toxin sequences

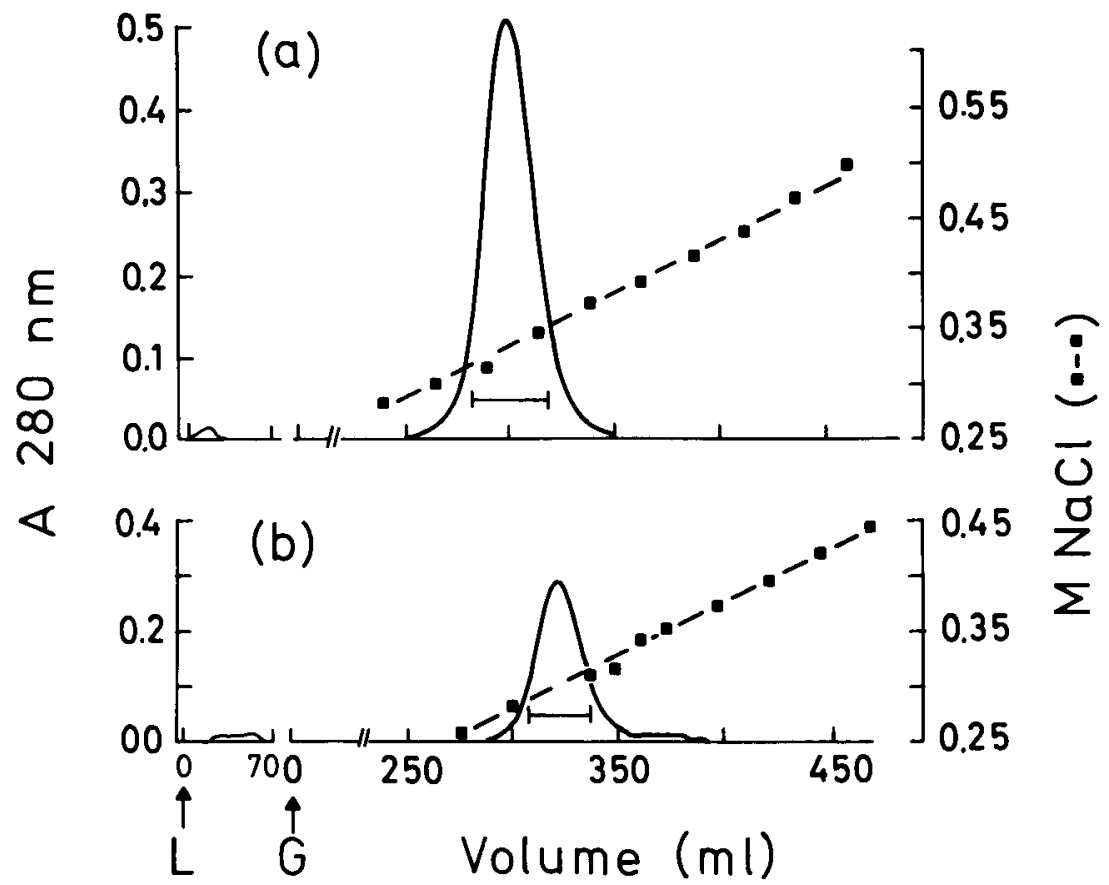

Figure 6. Final purification of Toxins III-8 and IV-5.

Fractions III-8 and IV-5 were rechromatographed on CM-cellulose under identical conditions to Figure 2 except that the gradient for IV -5 was from 0.0 to $0.45 \mathrm{M}-\mathrm{NaCl}$. The fractions $(2.4 \mathrm{ml})$ were pooled as indicated by the horizontal bars.

a) Fraction III-8. $34 \mathrm{ml}$ equilibration buffer containing 16.3 absorbance units at $280 \mathrm{~nm}$ was applied to the column. The pure Toxin III-8 recovered was $80 \%$ of the material applied.

b) Fraction IV-5. 9.5 absorbance units at $280 \mathrm{~nm}$ in $64 \mathrm{ml}$ equilibration buffer was loaded. Toxin IV-5 recovered free of contaminants constituted $61 \%$ of the material applied. $\mathrm{L}=$ loading. $\mathrm{G}=$ start of gradient.

peak was pooled (Figure 7) and lyophilized prior to sequence determination.

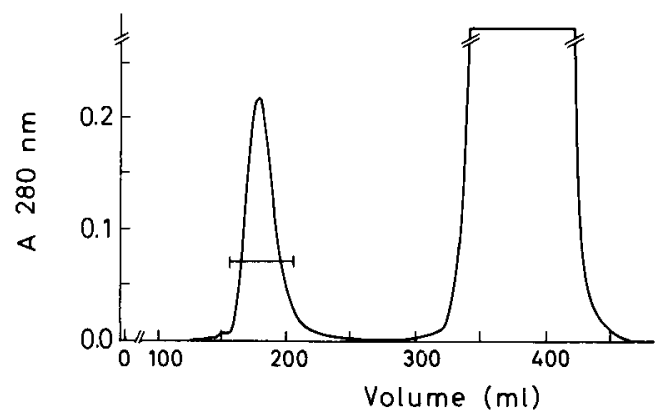

Figure 7. Gel filtration of alkylated Toxin III-10.

One $\mathrm{mg}$ of the reduced alkylated toxin was loaded on the column $(2.5 \times 120 \mathrm{~cm}$. Sephadex G-50, fine $)$ and eluted with $20 \%$ acetic acid. The flow rate was $30 \mathrm{ml} \cdot \mathrm{h}^{-1}$ and fractions of $5 \mathrm{ml}$ were collected. The fractions corresponding to the first peak were pooled as indicated by the horizontal bar. The recovery was quantitative.

\subsection{Amino acid analysis}

Samples for amino acid analysis were hydrolyzed in vacuo for 24 and 48 hours at $110^{\circ} \mathrm{C}$ in $5.7 \mathrm{M}-\mathrm{HCl}$. The amino acid analyses were performed on a Durrum D-500 amino acid analyser. The values for serine and threonine were obtained by extrapolation to zero time, whereas the values for valine and isoleucine were obtained after 48 hours hydrolysis. Half-cystine was determined as pyridylethyl cysteine. All results are expressed as molar ratios.

\subsection{Amino acid sequence determination}

Automated EDMAN degradation was performed using a Beckman $890 \mathrm{C}$ Sequencer according to the procedure of EDMAN \& BEGg (5). The use of THEED instead of Quadrol as coupling buffer has been previously described $(2,10)$. Beckman program 122974 (single cleavage, fast 
Table I.

Recovery and lethality of chromatographic components

\begin{tabular}{|c|c|c|c|}
\hline Column used & Protein component & $\%$ Recovery al & Lethality $^{\text {b) }}$ \\
\hline $\begin{array}{l}\text { Sephadex G-50 } \\
\text { (Fig. 1) }\end{array}$ & $\begin{array}{l}\text { Soluble venom } \\
\text { Fraction I } \\
\text { Fraction II } \\
\text { Fraction III } \\
\text { Fraction IV } \\
\text { protein recovered }\end{array}$ & $\begin{array}{l}100 \\
11.4 \\
41.3 \\
27.8 \\
19.5 \\
83\end{array}$ & $\begin{array}{l}25 \\
\text { nontoxic } \\
\text { lethal } \\
\text { lethal } \\
\text { lethal }\end{array}$ \\
\hline $\begin{array}{l}\text { CM-cellulose } \\
\text { (Fig. 2) }\end{array}$ & $\begin{array}{l}\text { Fraction II } \\
\text { unbound protein } \\
\text { II-1 } \\
\text { II-2 } \\
\text { II-3 } \\
\text { II-4 +5 } \\
\text { II-6 } \\
\text { II-7 } \\
\text { II-8 } \\
\text { II-9 } \\
\text { II-10 } \\
\text { II-11 } \\
\text { side-tubes } \\
\text { protein recovered }\end{array}$ & $\begin{array}{r}100 \\
0.5 \\
1.4 \\
3.7 \\
1.4 \\
17.5 \\
26.7 \\
10.2 \\
1.2 \\
3.9 \\
2.5 \\
29.7 \\
1.3 \\
95.3\end{array}$ & $\begin{array}{l}\text { not tested } \\
\text { not tested } \\
\text { non toxic } \\
\text { non toxic } \\
\text { non toxic } \\
\text { non toxic } \\
\text { non toxic } \\
\text { toxic } \\
\text { lethal } \\
\text { lethal } \\
\text { lethal } \\
\text { non toxic }\end{array}$ \\
\hline $\begin{array}{l}\text { CM-cellulose } \\
\text { (Fig. 3) }\end{array}$ & $\begin{array}{l}\text { Fraction III } \\
\text { unbound protein } \\
\text { III-1 } \\
\text { III-2 } \\
\text { III-3 } \\
\text { III-4 } \\
\text { III-5 } \\
\text { III-6 } \\
\text { III-7 } \\
\text { III-8 } \\
\text { III-9 } \\
\text { III-10 } \\
\text { side tubes }{ }^{\text {c }} \\
\text { protein recovered }\end{array}$ & $\begin{array}{r}100 \\
0.8 \\
2.9 \\
2.0 \\
2.1 \\
2.3 \\
5.9 \\
11.5 \\
24.9 \\
16.6 \\
8.1 \\
22.4 \\
0.5 \\
95.7\end{array}$ & $\begin{array}{l}\text { not tested } \\
\text { non toxic } \\
\text { non toxic } \\
\text { non toxic } \\
\text { non toxic } \\
\text { non toxic } \\
\text { toxic } \\
\text { lethal } \\
\text { lethal } \\
\text { toxic } \\
\text { lethal } \\
\text { not lested }\end{array}$ \\
\hline $\begin{array}{l}\text { CM-cellulose } \\
\text { (Fig. 4) }\end{array}$ & $\begin{array}{l}\text { Fraction IV } \\
\text { IV-1 (unbound protein) } \\
\text { IV-2 } \\
\text { IV-3 } \\
\text { IV-4 } \\
\text { IV-5 } \\
\text { IV-6 } \\
\text { IV-7 } \\
\text { side-tubes } \\
\text { protein recovered }\end{array}$ & $\begin{array}{r}100 \\
59.0 \\
3.0 \\
17.2 \\
1.0 \\
12.8 \\
6.0 \\
0.3 \\
0.7 \\
98.3\end{array}$ & $\begin{array}{l}\text { non toxic } \\
\text { not tested } \\
\text { non toxic } \\
\text { not tested } \\
\text { lethal } \\
\text { lethal } \\
\text { toxic } \\
\text { not tested }\end{array}$ \\
\hline
\end{tabular}

a) The values reported are percentages calculated from the number of absorbance units at $280 \mathrm{~nm}$ recovered.

b) Protein was injected intraperitoneally into $20 \mathrm{~g}$ mice. Numerical value is microgram of protein required to kill $50 \%$ of a test group (LD 50 ). When small amounts of toxin required a qualitative assay then $20-40, \mu \mathrm{g}$ of protein was injected into one or two mice. The terms »non-toxic«, »toxic« and "lethal« are defined in section 2.2 .

c) Absorbance from tubes located in troughs between peaks. 
protein Quadrol) was used throughout the analyses.

All samples were applied to the cup dissolved in $30 \%$ acetic acid and dried using the Beckman Sample Application Subroutine (Program 02772). In all cases Polybrene (22) and the dipeptide glycylalanine ( $3 \mathrm{mg}$ Polybrene and 100 nmoles dipeptide in $300 \mu \mathrm{l} \mathrm{H}_{2} \mathrm{O}$ ) were added to the cup and two steps of degradation were performed prior to introduction of the reduced alkylated toxin. Addition of glycylalanine with Polybrene appears to eliminate reactive sites in the Polybrene which could cause blockage of the amino terminus of the protein (toxin) to be sequenced. The loss of available amino terminal groups can be up to $50 \%$ when small amounts of protein are being sequenced and no precautions to avoid this loss are taken (9).

Identification of PTH-amino acids was made by HPLC using a Hewlett-Packard chromato- graph 1084 B as described previously (21). Additional information was obtained from thin layer chromatography (13).

\section{RESULTS AND DISCUSSION}

The purification procedure followed here was slightly different from that previously used (14). The larger Sephadex G-50 column allowed the fractionation of the soluble venom into at least four distinct fractions (Figure 1). Fraction I was not toxic to mice but contains hyaluronidase activity as previously reported (14). Fractions II to IV, however, were all lethal to mice and were further separated using CM-cellulose with a different buffer system than before. The initial CM-cellulose chromatography provided several components as shown in Figures 2 to 4 . The yield and toxicity of all chromatographic steps is listed in Table I. The four major lethal fractions;

Table II.

Amino acid composition of toxins from the venom of Tityus serrulatus Lutz and Mello ${ }^{a}$

\begin{tabular}{|c|c|c|c|c|}
\hline Amino Acid & Toxin II-11 & Toxin III- 10 & Toxin III-8 & Toxin IV-5 \\
\hline Asp & $3.7 \quad(4)^{f)}$ & $3.8 \quad(4)^{f)}$ & $4.9 \quad(5)^{f)}$ & $9.5(10)^{f)}$ \\
\hline$\left.T_{h} r^{b}\right)$ & $0.9 \quad$ (1) & $1.1 \quad(1)$ & $1.9 \quad(2)$ & $1.9 \quad(2)$ \\
\hline Ser ${ }^{b)}$ & $3.8 \quad(4)$ & $3.9 \quad(4)$ & 2.8 & $2.8 \quad$ \\
\hline Glu & 3.1 & 3.3 (3) & $2.2 \quad(2)$ & $2.0 \quad(2)$ \\
\hline Pro & 3.0 & 2.8 & $2.8 \quad(3)$ & $2.8 \quad$ \\
\hline Gly & $8.0 \quad(8)$ & $8.0 \quad(8)$ & $6.0 \quad(6)$ & $4.0 \quad$ (4) \\
\hline Ala & 3.0 & 3.0 & $5.6 \quad(6)$ & $2.9 \quad$ \\
\hline $\mathrm{Val}^{\mathrm{c})}$ & $1.8 \quad(2)$ & 2.0 & $1.9 \quad(2)$ & $1.8 \quad(2)$ \\
\hline Met & $0.9 \quad(1)$ & $0.9 \quad$ (1) & $0.9 \quad(1)$ & $0.0 \quad(0)$ \\
\hline $\mathrm{Ile}^{\mathrm{c})}$ & $1.9 \quad(2)$ & $2.0 \quad(2)$ & $1.8 \quad(2)$ & $1.8 \quad(2)$ \\
\hline Leu & 3.0 & $3.1 \quad(3)$ & 1.3 & 3.0 \\
\hline Tyr & $4.5 \quad(5)$ & $4.7 \quad$ (5) & $5.3 \quad(5)$ & 7.7 \\
\hline Phe & 1.0 & 1.1 & $2.9 \quad(3)$ & $0.0 \quad(0)$ \\
\hline His & 1.0 & 1.0 & 2.7 & 1.0 \\
\hline Lys & $5.5 \quad(6)$ & $6.2 \quad(6)$ & $6.9 \quad(7)$ & $6.7 \quad(7)$ \\
\hline Arg & 2.6 & $2.8 \quad$ & $1.0 \quad(1)$ & $0.0 \quad(0)$ \\
\hline Half-Cys $\left.{ }^{d}\right)$ & $8.0 \quad(8)$ & $6.3 \quad(6-8)$ & $6.5 \quad(6-8)$ & $7.0 \quad(6-8)$ \\
\hline Trpe) & n.d. & n.d. & n.d. & n.d. \\
\hline $\begin{array}{l}\text { Total } \\
\text { mol.wt.g) }\end{array}$ & $\begin{array}{l}58+\operatorname{Trp} \\
6313\end{array}$ & $\begin{array}{l}58+\operatorname{Trp} \\
6313\end{array}$ & $\begin{array}{l}60+\operatorname{Trp} \\
6569\end{array}$ & $\begin{array}{l}58+\operatorname{Trp} \\
6525\end{array}$ \\
\hline
\end{tabular}

a) residues $/$ mole based on glycine $=8,8,6$, and 4 for II- 11 , III-10, III- 8 and IV-5 respectively,

b) extrapolated to zero time,

c) value after 48 hours of hydrolysis,

d) determined as pyridylethyl-cysteine after reduction and alkylation (recoveries varied from 65-95\%),

e) n.d. - not determined,

f) numbers in parenthesis represent the nearest integer,

g) molecular weight calculated without tryptophan and assuming 8 half-cystines. 
II-11, III-8, III-10 and IV-5, were dialyzed prior to rechromatography on $\mathrm{CM}$-cellulose columns (Figures 5 and 6) and were found to be homogeneous (a single band) on polyacrylamide gel electrophoresis in the $\beta$-alanine-urea system (19). The lethality to mice was in the same range of magnitude for each i.e., approximately 10 to $20 \mu \mathrm{g}$ toxin (from amino acid analysis assuming a molecular weight of 7000 ) per mouse of $20 \mathrm{~g}$. The amino acid composition of these four toxic fractions is found in Table II.

Clearly, the chemical characterization of the major toxic components by automatic Edman degradation is of the utmost importance for determining the exact nature and number of toxins in the scorpion venoms. Prior to sequencing, the individual toxic fractions had been reduced and pyridylethylated.

Fourty-six cycles in the Sequencer using 50 nmoles of the reduced pyridylethylated-Toxin II-1 I established the N-terminal sequence through residue 41 confirming the first 29 amino acid residues previously published (14). Only one amino acid residue was found in each step and the repetitive yield was $95 \%$ (Figure 8 ).
The first fourty-one amino acid residues from the $\mathrm{N}$-terminal were identified using 100 nmoles of PE-toxin III-8 in the Sequencer. The repetitive yield was $96 \%$ and the sequence is found in Figure 8.

PE-toxin III-10 (90 nmoles) was submitted to 46 cycles of degradation with a repetitive yield of $95 \%$. The first fourty-one amino acids were identified and are identical with those determined for II-11. Because the amino acid analysis also appeared to be the same, III-10 and II-11 are presented as one sequence in Figure 8.

Reduced alkylated fraction IV -5 (50 nmoles) was sequenced successfully through residue fourty-one. The repetitive yield was $96 \%$ through step 37. The single unique amino acid sequence is presented in Figure 8.

From the amino acid compositions and the sequence comparison of the toxins, it would appear that there are at least three distinct major toxins in the venom of Tityus serrulatus.

The elution pattern of the soluble venom on Sephadex G-50 and the subsequent CM-cellulose chromatography suggested that toxin II-1I and toxin III-10 were two distinct species. However,
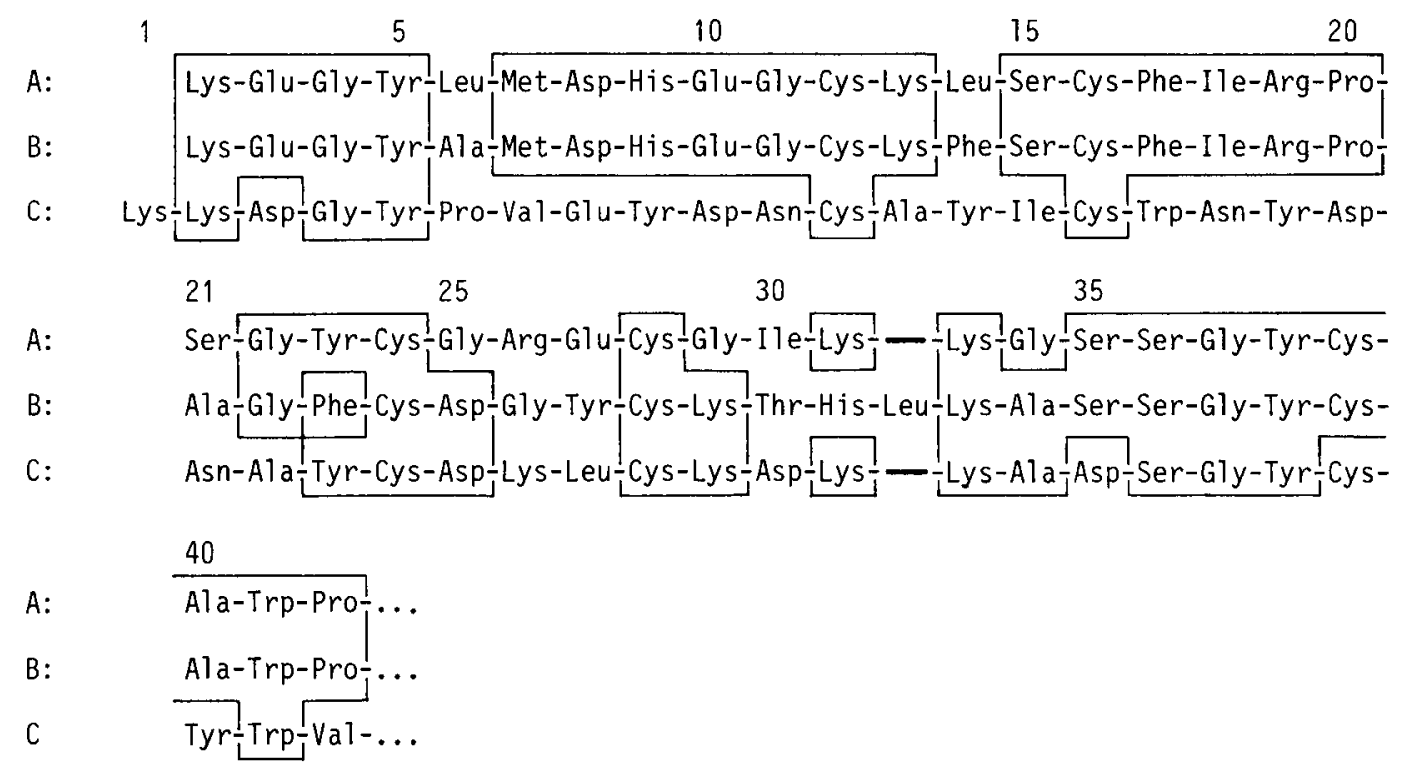

Figure 8. Comparison of the amino terminal amino acid sequences of A: Toxin II-1I (identical with III-10), B: Toxin III-8, and C: Toxin IV-5 from the scorpion Tityus serrulatus Lutz and Mello.

Half-cystines have been aligned in all three sequences and gaps are introduced to maximize homology. The numbering system for amino acid positions has been adapted accordingly. Residues which are invariant in the toxins are enclosed in boxes. 
from the amino acid composition (Table II) and the amino terminal sequence data presented here we can only surmise that the two toxin fractions are identical. For this reason and until the complete sequence is finished and the disulphide bridges are placed we refer only to toxin II-11.

Comparison of the amino terminal sequences of the toxins was made after alignment of the invariant half-cystine residues and introduction of gaps in order to maximize the sequence homology. As can be seen in Figure 8 there is striking similarity between Toxin III-8 and Toxin II-11 (III-10) with identical amino acid residues in 29 of the 41 positions determined. If, however, Toxin IV-5 is compared with either III- 8 or II- 11 the number of identical residues drops to 15 for both toxins. There are several areas of high homology which are common to all three sequences: positions $2-5,23-25$ and particularly 33-42. This latter area, containing 10 amino acid residues, is identical in 6 positions in all three toxins. Nevertheless, the low number of identical residues is unusual for toxins from the same animal. This low degree of homology in the amino terminal sequence is the first such case reported. All other scorpion venoms studied, both North American and North African show extensive homology among the variant toxins in the same venom (20), Another interesting finding is that Toxin IV-5 has sequence regions which are homologous to North African scorpions and at the same time other sequence regions which are more similar to North American scorpions. The North African scorpion Buthus occitanus paris toxin I and II has the sequence $\mathrm{Asn}_{11}-\mathrm{Cys}_{12}-\mathrm{Ala}_{13}-\mathrm{Tyr}_{14}$ (20) while Androctonus mauretanicus mauretanicus Toxin $\mathrm{V}$, also from North Africa, has the sequence $\mathrm{Asn}_{19}-\mathrm{Ala}_{20}-\mathrm{Ty}_{21}-\mathrm{Cys}_{22}-\mathrm{Asp}_{23}$ (20) both sequences present in Toxin IV-5. The most striking example of sequence homology when comparing IV-5 with North American scorpion toxins is the region: Gly ${ }_{37}-\mathrm{Tyr}_{38}-\mathrm{Cys}_{39}-\mathrm{Tyr}_{40}$ which is also found in our Toxins II- 11 and III-8 along with several variant toxins from Centruroides sculpturatus EwING (1) and from Centruroides noxius HoffmanN (see accompanying paper).

Toxins II- 1 I and III-8 are typical of the North American scorpion toxins, having amino terminal sequences which are identical in several regions with those of Centruroides noxius
Hoffmann, Centruroides sculpturatus EwING and Centruroides suffusus suffusus $(1,20)$. Examples of these sequence regions are Lys2$\mathrm{Glu}_{3}-\mathrm{Gly}_{4}-\mathrm{Tyr}_{5}, \mathrm{Gly}_{11}-\mathrm{Cys}_{12}-\mathrm{Lys}_{13}$, and Gly $37-$ $\mathrm{Tyr}_{38}$-Cys 39 -Ala 1 .

Also worth noting is the repeating sequence which occurs in the toxins of $T$, serrulatus. In both Toxin II-1I and III-8 the recurring GlyTyr-Cys is found at positions $22-24$ and 37-39, while Gly-Tyr repeats at positions $4-5$ and $37-$ 38 in all three toxins. Cys-Lys can be found at positions 12-13 and 28-29 in Toxin III-8 and at positions $12-13$ in Toxin II- 11 and positions 28-29 in Toxin IV -5 .

Little is known about the mode of action of these toxins, except for Tityustoxin, another toxin obtained from $T$. serrulatus venom by Diniz et al. (4). The scarcity of data available on the amino terminal amino acid sequence of Tityustoxin suggests that Toxin IV-5 and Tityustoxin are possibly the same molecule.

Toxin II-11 $(\gamma)$ is now being studied (Carbone, W anke, Prestipino, Maelicke, PosSANI, unpublished observations) in the isolated squid giant axon under voltage clamp experiments. It appears to be a good reversible and specific blocker of the voltage dependent sodium channel (inward current, only).

Presently we are carrying out experiments for the complete elucidation of the primary structure of these toxins as well as the confirmation of the physiological effects recently observed.

\section{ACKNOWLEDGEMENTS}

Thanks are due to the Director and the Conselho de Pesquisas of the Instituto Butantan, São Paulo, Brazil for their generous gift of $\mathrm{T}$. serrulatus venom. The excellent technical assistance of Mss. Lone Sørensen and BodiL CoRneluussen is gratefully acknowledged. The authors wish to express their appreciation to Professor M. OtTesen of Carlsberg for allowing us the use of the Sequencer facilities and to Professor A. MAELICKE of the Max-PlanckInstitute, Dortmund for his continuing support throughout the course of this work.

\section{REFERENCES}

1. Babin, D. R., D. D. WATT, S. M. Goos \& R. V. MLEJNEK: Amino acid sequences of neurotoxic 
protein variants from the venom of Centruroides sculpturatus Ewing. Arch. Biochem. Biophys. 164, 694-706 (1974)

2. BegG, G. E. \& F. J. Morgan: A non-volatile buffer with improved performance in automated protein sequencing. FEBS Lett. 66. 243-245. (1976)

3. Dent, M. A. R., L. D. Possani, G. A. Ramirez \& P. L. Fletcher, Ir.: Purification and characterization of two mammalian toxins from the venom of the Mexican scorpion Centruroides noxius Hoffmann. Toxicon 18, 343-350 (1980)

4. DiNiz, C. R.: Chemical and pharmacologic aspects of Tityinae venoms. In: Arthropod venoms. Handbook of Experimental Pharmacology, S. Bettini, ed., Springer-Verlag, Berlin, Heidelberg \& New York, 48, pp. 379-394 (1978)

5. Edman, P. \& G. BegG: A protein sequenator. Eur. J. Biochem. 1, 80-91 (1967)

6. Edman, P. \& A. Henschen: Sequence determination. In: Protein Sequence Determination. Molecular Biology Biochemistry and Biophysics 8 , 2nd edition, S. B. Needleman, ed., SpringerVerlag, Berlin, Heidelberg and New York, pp. 232-279 (1975)

7. Fontecilla-Camps, J. C., R. J. Almassy, F. L. Suddarh, D. D. Watt \& C. E. Bugg: Threedimensional structure of a protein from scorpion venom: A new structural class of neurotoxins. Proc. Natl. Acad. Sci. U.S.A. 77. 6496-6500 (1980)

8. Gillesple, J. I. \& H. Meves: The effect of scorpion venoms on the sodium currents of the squid giant axon. J. Physiol. 308, 479-499 (1980)

9. Hunkapiller, M. W. \& L. E. Hood: Direct microsequence analysis of polypeptides using an improved sequanator, a non-protein carrier (Polybrene), and high pressure liquid chromatog. raphy. Biochemistry 17, 2124-2133 (1978)

10. Johansen, J. T., C. Overballe-Petersen, B. Martin, V. Hasemann \& I. Svendsen: The complete amino acid sequence of copper, zinc superoxide dismutase from Saccharomyces cerevisiae. Carlsberg Res. Commun. 44, 201-217 (1979)

1 1. Kopeyan, C., G. Martinez, S. Lissitzky, F. Miranda \& H. Rochat: Disulphide bonds of toxin II of the scorpion Androctonus australis Hector. Eur. J. Biochem. 47, 483-489 (1974)

12. Kopeyan, C., G. Martinez \& H. Rochat: Amino acid sequence of neurotoxin III of the scorpion Androctonus australis Hector. Eur. J. Biochem. 94, 609-615 (1979)

13. Kulbe, K. D.: Micropolyamide thin-layer chro- matography of phenylthiohydantoin amino acids (PTH) at the subnanomolar level. A rapid microtechnique for simultaneous multisample identification after automated Edman degradations. Anal. Biochem. 59, 564-573 (1974)

14. Possani, L. D.. A. C. Alagon. P. L. Fletcher, Jr. \& B. W. ERICKSON: Purification and properties of mammalian toxins from the venom of the Brazilian scorpion Tiluts serrulaus Luz and Mello. Arch. Biochem. Biophys. 180, 394-403 (1977)

15. Possani, L. D., P. L. Fi.etcher, Jr., A. B. C. Alagon, A. C. Alagon \& J. Z. Julia: Purification and characterization of a mammalian toxin from venom of the Mexican scorpion Centruroides limpidus tecomanus Hoffmann. Toxicon 18, 175-183(1980)

16. Possani. L. D., B. Martin, J. Mochca-Morales \& I. SVEndSEN: N-terminal sequence of toxin IV-5 from the venom of the scorpion Tityus serrulatus. Abstract to the 4th European Symposium on Animal, Plant and Microbial Toxins, Marseille, France, 24-27 June, 1981

17. Possani, L. D., W. E. Steinmetz, M. A. R. Dent, A. C. Alagon \& K. Wüthrich: Preliminary spectroscopic characterization of six toxins from Latin American scorpions. Biochim. Biophys. Acta 669, 183-192 (1981)

18. Ray, R. \& W. A. Catteral: Membrane potential dependent binding of scorpion toxin to the action potential sodium ionophore. Studies

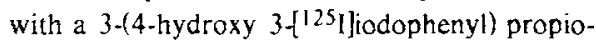
nyl derivative. J. Neurochem. 31, 397-407 (1978)

19. Reisfeld, R. A., U. J. Lewis \& D. E. Williams: Disk electrophoresis of basic proteins and peptides on polyacrylamide gels. Nature $281-$ 283 (1962)

20. Rochat, H., P. Bernard \& F. Couraud: Scorpion toxins: Chemistry and mode of action. Adv. Cytopharm. 3, 325-334 (1979)

21. Svendsen, 1., B. Martin \& I. Jonassen: Characteristics of hiproly barley III. Amino acid sequences of two lysinerich proteins. Carlsberg Res. Commun. 45, 79-85 (1980)

22. TARr, G. E.. J. F. Beecher, M. Bell \& D. J. MCKEAN: Polyquarternary amines prevent peptide loss from sequenators: Anal. Biochem. 84 , 622-627 (1978)

23. Zlotkin, E., F. Miranda \& H. Rochat: Chemistry and pharmacology of Buthinae scorpion venoms. In: Arthropod venoms. Handbook of Experimental Pharmacology, S. Bettini, ed.. Springer-Verlag, Berlin, Heidelberg and New York, 48, pp. 317-369 (1978) 